\title{
The Role of Adenosine A1 and A2A Receptors in the Caffeine Effect on MDMA-Induced DA and 5-HT Release in the Mouse Striatum
}

\author{
A. M. Górska • K. Gołembiowska
}

Received: 7 August 2014/Revised: 28 October 2014/ Accepted: 5 November 2014/Published online: 13 November 2014

(C) The Author(s) 2014. This article is published with open access at Springerlink.com

\begin{abstract}
Methylenedioxymethamphetamine (MDMA, "ecstasy") popular as a designer drug is often used with caffeine to gain a stronger stimulant effect. MDMA induces 5-HT and DA release by interaction with monoamine transporters. Co-administration of caffeine and MDMA may aggravate MDMA-induced toxic effects on DA and 5-HT terminals. In the present study, we determined whether caffeine influences DA and 5-HT release induced by MDMA. We also tried to find out if adenosine $\mathrm{A} 1$ and $\mathrm{A} 2 \mathrm{~A}$ receptors play a role in the effect of caffeine by investigating the effect of the selective adenosine A1 and A2A receptor antagonists, DPCPX and KW 6002 on DA and 5-HT release induced by MDMA. Mice were treated with caffeine $(10 \mathrm{mg} / \mathrm{kg}$ ) and MDMA (20 or $40 \mathrm{mg} /$ $\mathrm{kg}$ ) alone or in combination. DA and 5-HT release in the mouse striatum was measured using in vivo microdialysis. Caffeine exacerbated the effect of MDMA on DA and 5-HT release. DPCPX or KW 6002 co-administered with MDMA had similar influence as caffeine, but KW 6002 was more potent than caffeine or DPCPX. To exclude the contribution of MAO inhibition by caffeine in the caffeine effect on MDMA-induced increase in DA and 5-HT, we also tested the effect of the nonxanthine adenosine receptor antagonist CGS 15943A lacking properties of MAO activity modification. Our findings indicate that adenosine $\mathrm{A} 1$ and $\mathrm{A} 2 \mathrm{~A}$ receptor blockade may account for the caffeine-induced exacerbation of the MDMA effect on DA and 5-HT release and may aggravate MDMA toxicity.
\end{abstract}

Keywords MDMA · Caffeine - DA - 5-HT · Microdialysis $\cdot$ Mouse

\footnotetext{
A. M. Górska · K. Gołembiowska ( $₫)$

Institute of Pharmacology, Polish Academy of Sciences,

Smętna 12, 31-343 Kraków, Poland

e-mail:nfgolemb@cyf-kr.edu.pl
}

\section{Introduction}

3,4-Methylenedioxymethamphetamine (MDMA, "ecstasy") is a designer drug structurally related to the hallucinogenic mescaline and amphetamine. Its illicit use by "rave" party participants is a serious social problem. In addition, it induces neurotoxicity observed in experimental models and in humans. The data obtained in laboratory animals in vivo have revealed that MDMA interacts with monoamine transporters to stimulate non-exocytotic release of serotonin (5-HT), dopamine (DA), and noradrenaline (NA) (Baumann et al. 2005; Gudelsky and Nash 1996; Sulzer et al. 2005; Yamamoto and Spanos 1988). MDMA has mood-enhancing properties and hallucinogenic effects in humans (Sulzer et al. 2005). Its acute peripheral symptoms include hyperthermia, increased blood pressure, tachycardia, acute renal and liver failure, convulsions, and cerebral hemorrhage resulting in death (Capela et al. 2009). A longterm MDMA intake causes neurotoxic effects to the serotonergic fibers in the forebrain leaving raphe cell bodies unaffected (Xie et al. 2006) as observed in rats and nonhuman primates (Capela et al. 2009). A wide variety of abused drugs are often found in ecstasy tablets to gain a stronger stimulant effect and such combinations of MDMA with other compounds may be extremely toxic leading to enhanced adverse effects. For instance, high amount of caffeine has been often detected in ecstasy tablets. Individuals exposed to excessive doses of caffeine presented anxiety, agitation, hallucinations, convulsions, and mimicking the effects of stimulant recreational drugs (Davies et al. 2012). The primary action of caffeine is to block adenosine $\mathrm{A} 1$ and $\mathrm{A} 2 \mathrm{~A}$ receptors which leads to secondary effects on many classes of neurotransmitters (Fredholm et al. 1999). Inhibitory adenosine A1 receptors are present in almost all brain areas and their stimulation can suppress 
neuronal excitability (Fredholm et al. 1994). Adenosine A2A receptors concentrated in the dopamine rich areas of the brain activate adenylyl cyclase and some types of voltage-sensitive $\mathrm{Ca}^{2+}$-channels (Fredholm et al. 1994). Thus, adenosine $\mathrm{A} 1$ and $\mathrm{A} 2 \mathrm{~A}$ receptors have opposing actions at cellular and neuronal levels. The central stimulatory effect of caffeine seems to be related with the blockade of adenosine A1 receptors causing increases of 5-HT, DA and NA turnover (Hadfield and Milio 1989), elevation of DA level in the striatum (Morgan and Vestal 1989). In addition, an A1 antagonist was shown to enhance locomotion in rodents (Popoli et al. 1996). A2A receptors are abundant in the striatum and nucleus accumbens where they are expressed on the GABAergic neurons or are present on glutamatergic neuronal terminals thus controlling the basal ganglia output and input neurons (Svenningsson et al. 1998). There is evidence that A2A receptors oppose the effects of dopamine D2 receptors (Ferré et al. 1997). Thus, an inhibition of A2A receptors by caffeine can increase rotation behavior induced by dopamine agonists (Fenu et al. 1997), while dopamine receptor antagonists can inhibit the stimulatory effects of caffeine on locomotion (Garret and Holtzman 1994). Caffeine co-administered with MDMA potentiated the MDMA effect on extracellular DA level in the striatum of anesthetized rats (Ikeda et al. 2011) and enhanced MDMA-induced DA release from the rat striatal slices and this effect was suggested to be mediated via adenosine A1 receptors (Vanattou-Saïfoudine et al. 2011). On the other hand, exacerbation of MDMA-induced hyperthermia by caffeine is proposed to result from the inhibition of adenosine A2A receptors (Vanattou-Saïfoudine et al. 2010). Hyperthermia and neuroinflammation after acute but not chronic administration of caffeine and MDMA have been reported to cause neurotoxic effects in rodents (Khairnar et al. 2010; McNamara et al. 2006; Ruiz-Medina et al. 2013; Vanattou-Saïfoudine et al. 2011). In contrast to rats and nonhuman primates, MDMA produces rather dopaminergic neurotoxicity in mice (Colado et al. 2001). However, depending on MDMA dosage and mouse strain, it can cause 5-HT neurotoxicity, as well (Fornai et al. 2004). According to the hypothesis of Sprague et al. (1998), acute doses of MDMA induce 5-HT and DA release. 5-HT released by MDMA decreases inhibitory GABAergic transmission via 5-HT2A/C receptors situated on GABA interneurons, this effect is followed by increased DA release. The excessive DA transported into serotonergic terminals may be metabolized through MAO-B into 3,4-dihydroxyphenylacetic acid (DOPAC) and hydrogen peroxide which would result in free radical generation. Thus, either DA or 5-HT may be a determinant of MDMA neurotoxicity. Co-administration of caffeine and MDMA may aggravate MDMA-induced toxic effects on DA and 5-HT terminals via the mechanism engaging adenosine $\mathrm{A} 1 / \mathrm{A} 2 \mathrm{~A}$ receptors. To date, there are no data about in vivo effects of caffeine and MDMA coadministration in mice. Therefore, in our study, we were interested in investigating whether acute treatment with caffeine affects MDMA-induced release of DA and 5-HT in the mouse striatum using in vivo microdialysis. In addition, we attempted to explain the specific role of adenosine A1 and A2A receptors in the caffeine effect by investigating the influence of selective adenosine $\mathrm{A} 1$ and $\mathrm{A} 2 \mathrm{~A}$ receptor antagonists, 8-cyclopentyl-1,3-dipropylxanthine (DPCPX), and (E)-1,3-diethyl-8-(3,4-dimethoxystyryl)-7-methyl-3,7dihydro-1H-purine-2,6-dione (KW 6002) on the MDMAinduced DA and 5-HT release. To exclude the contribution of MAO inhibition by caffeine in the caffeine effect on MDMA-induced increase in DA and 5-HT, we also tested the effect of the nonxanthine adenosine receptor antagonist CGS 15943A lacking properties of MAO activity modification.

\section{Materials and Methods}

\section{Animals}

Experiments were performed on adult male (8-10 weeks old) C57BL/6J inbred mice. The animals were housed 5-7 per cage, under a 12-h light/12-h dark cycle, with free access to standard food and tap water. The experiments were conducted in accordance with the European Union guidelines regarding the care and use of laboratory animals (Council Directive 86/609/EEC of November 24, 1986) and were approved by the II Local Bioethics Commission (Kraków, Poland).

\section{Drugs and Reagents}

Caffeine, DPCPX (8-cyclopentyl-1,3-dipropylxanthine) and CGS 15943A (9-chloro-2-(2-furyl)[1,2,4]triazolo[1,5c]quinazoline-5-amine) were obtained from Sigma-Aldrich (Poznań, Poland), while KW 6002 [(E)-1,3-diethyl-8-(3,4dimethoxystyryl)-7-methyl-3,7-dihydro-1H-purine-2,6-dione] was purchased from Selleckchem (USA). Caffeine was dissolved in $0.9 \% \mathrm{NaCl}$, while DPCPX and KW 6002 were dissolved initially in dimethyl sulfoxide (DMSO) and were then suspended in $0.3 \%$ Tween 80 . All injections were done with intraperitoneal route and control animals received respective vehicles. The chemicals used for HPLC were purchased from Merck (Warsaw, Poland).

\section{Brain Microdialysis}

Animals were anesthetized with ketamine $(7.5 \mathrm{mg} / \mathrm{kg})$ and xylazine $(1 \mathrm{mg} / \mathrm{kg})$, and a vertical microdialysis probes were implanted into the striatum using the following coordinates: $\mathrm{AP}+1.0, \mathrm{~L}+1.8, \mathrm{~V}-3.8$ (Paxinos and 
Franklin 2001). On the next day, probe inlets were connected to a syringe pump (BAS, IN, USA) which delivered a CSF composed of [mM]: $\mathrm{NaCl} 147, \mathrm{KCl} 2.7, \mathrm{MgCl}_{2}$ 1.0, $\mathrm{CaCl}_{2}$ 1.2; $\mathrm{pH} 7.4$ at a flow rate of $1.5 \mu \mathrm{l} / \mathrm{min}$. After $1 \mathrm{~h}$ of the washout period, three basal dialysate samples were collected every $30 \mathrm{~min}$; then animals were injected with appropriate drugs in doses indicated in figure captions and fraction collection continued for $270 \mathrm{~min}$. At the end of the experiment, the mice were sacrificed and their brains were histologically examined to validate the probe placement.

\section{Analytical Procedure}

DA, 5-HT, 3-MT, 3,4-dihydroxyphenylacetic acid (DOPAC), homovanillic acid (HVA), and 5-hydroxyindoleacetic acid (5HIAA) were analyzed by high-performance liquid chromatography (HPLC) with coulochemical detection. Chromatography was performed using an Ultimate 3000 System (Dionex, USA), coulochemical detector Coulochem III (model 5300, ESA, USA) with 5020 guard cell, 5014B microdialysis cell and Hypersil Gold C18 analytical column $(3 \times 100 \mathrm{~mm})$. The mobile phase was composed of $0.1 \mathrm{M}$ potassium phosphate buffer adjusted to $\mathrm{pH} 3.6,0.5 \mathrm{mM}$ EDTA, $16 \mathrm{mg} / \mathrm{L}$ 1-octanesulfonic acid sodium salt, and $2 \%$ methanol. The flow rate during analysis was set at $0.7 \mathrm{ml} / \mathrm{min}$. The applied potential of a guard cell was $+600 \mathrm{mV}$, while those of microdialysis cells were: $E_{1}=-50 \mathrm{mV}$, $E_{2}=+300 \mathrm{mV}$ with a sensitivity set at $50 \mathrm{nA} / \mathrm{V}$. The chromatographic data were processed by Chromeleon v. 6.80 (Dionex, USA) software run on a PC computer.

\section{Data Analysis}

All obtained data were presented as a percent of the basal level assumed as $100 \%$. The statistical significance was calculated using a repeated measures ANOVA or where appropriate a one-way ANOVA, followed by Tukey's posthoc test. The results were considered statistically significant when $P<0.05$.

\section{Results}

The Effect of Caffeine and Adenosine A1 and A2A Receptor Antagonists DPCPX and KW 6002 on DA Release Induced by MDMA in the Striatum of the Mouse

MDMA at doses of 20 and $40 \mathrm{mg} / \mathrm{kg}$ significantly $(P=0.0001)$ increased DA release by ca. 560 and $1,400 \%$ of the basal level at $60 \mathrm{~min}$ after administration. Caffeine at a dose of $10 \mathrm{mg} / \mathrm{kg}$, but not at a dose of $5 \mathrm{mg} / \mathrm{kg}$ (results not shown) markedly enhanced the effect of MDMA on DA release given at a dose of $40 \mathrm{mg} / \mathrm{kg}(P=0.0002)$; however, it did not affect significantly the increase in DA release produced by MDMA in a lower dose of $20 \mathrm{mg} / \mathrm{kg}$ (Fig. 1a, b). Repeated measures ANOVA of these data showed a statistically significant effect of treatment groups $\left[F_{5,28}=262, \quad P=0\right], \quad$ sampling period $\left[F_{8,224}=312\right.$, $P=0]$, and the interaction between treatment groups and sampling period $\left[F_{40,224}=122, P=0\right]$.

The selective adenosine A1 receptor antagonist DPCPX at a dose of $2.5 \mathrm{mg} / \mathrm{kg}$ but not at a dose of $1.25 \mathrm{mg} / \mathrm{kg}$ significantly $(P=0.0001)$ enhanced the effect of MDMA $(40 \mathrm{mg} / \mathrm{kg})$ on DA release (Fig. 1c). Repeated measures ANOVA showed a significant effect of treatment groups $\left[F_{5,26}=445, P=0\right], \quad$ sampling period $\left[F_{8,208}=245\right.$, $P=0]$, and the interaction between treatment groups and sampling period $\left[F_{40,208}=62, P=0\right]$.

The selective adenosine $\mathrm{A} 2 \mathrm{~A}$ receptor antagonist $\mathrm{KW}$ 6002 at both doses of 1.25 and $2.5 \mathrm{mg} / \mathrm{kg}$ significantly $(P=0.0001)$ increased the effect of MDMA (40 mg/kg) on DA release (Fig. 1d). Repeated measures ANOVA showed a significant effect of treatment groups $\left[F_{5,28}=627, P=0\right]$, sampling period $\left[F_{8,224}=194, P=0\right]$, and the interaction between treatment groups and sampling period $\left[F_{40,225}=\right.$ $78, P=0]$.

The basal extracellular DA level in dialysate fractions from the mouse striatum was $7.74 \pm 0.71(\mathrm{pg} / 10 \mu \mathrm{l}$, $n=103$ ) and no significant differences between experimental groups were observed.

The Effect of Caffeine and Adenosine A1 and A2A Receptor Antagonists DPCPX and KW 6002 on 5-HT Release Induced by MDMA in the Striatum of the Mouse

MDMA at doses of 20 and $40 \mathrm{mg} / \mathrm{kg}$ significantly $(P=0.0001)$ increased 5-HT release in the mouse striatum by ca. 389 and $510 \%$ of the basal level at $60 \mathrm{~min}$ after administration. Caffeine $(10 \mathrm{mg} / \mathrm{kg})$, but not at a dose of $5 \mathrm{mg} / \mathrm{kg}$ (results not shown) significantly increased the effect of both MDMA doses (20 and $40 \mathrm{mg} / \mathrm{kg}$ ) on 5-HT release ( $P=0.002$ and $P=0.0001$, respectively) (Fig. 2a, b). Repeated measures ANOVA showed a significant effect of treatment groups $\left[F_{5,26}=372, P=0\right]$, sampling period $\left[F_{8,208}=101, P=0\right]$, and the interaction between treatment groups and sampling period $\left[F_{40,208}=15, P=0\right]$.

A selective adenosine A1 receptor antagonist DPCPX at a dose of $2.5 \mathrm{mg} / \mathrm{kg}$ but not $1.25 \mathrm{mg} / \mathrm{kg}$ significantly $(P=0.0001)$ enhanced the effect of MDMA $(40 \mathrm{mg} / \mathrm{kg})$ on 5-HT release (Fig. 2c). Repeated measures ANOVA showed a significant effect of treatment groups $\left[F_{5,23}=\right.$ 618, $P=0]$, sampling period $\left[F_{8,184}=80, P=0\right]$, and 
Fig. 1 The effect of caffeine (CAF) and adenosine A1 and A2A receptor antagonists, DPCPX and KW $6002(\mathrm{KW})$ on DA release induced by MDMA in the mouse striatum. CAF (10 mg/kg), DPCPX (1.25 and $2.5 \mathrm{mg} / \mathrm{kg}$ ), and $\mathrm{KW}$ (1.25 and $2.5 \mathrm{mg} / \mathrm{kg}$ ) were injected simultaneously with MDMA 20 or $40 \mathrm{mg} / \mathrm{kg}$ as indicated with an arrow. Values are the mean $\pm \operatorname{SEM}(n=6-8$ animals). $* P<0.0001$ represents a significant difference in comparison to control group; " $a$ " $P<0.0002$ represents a significant difference in comparison to MDMA group (repeated measures ANOVA and Tukey's post-hoc test)
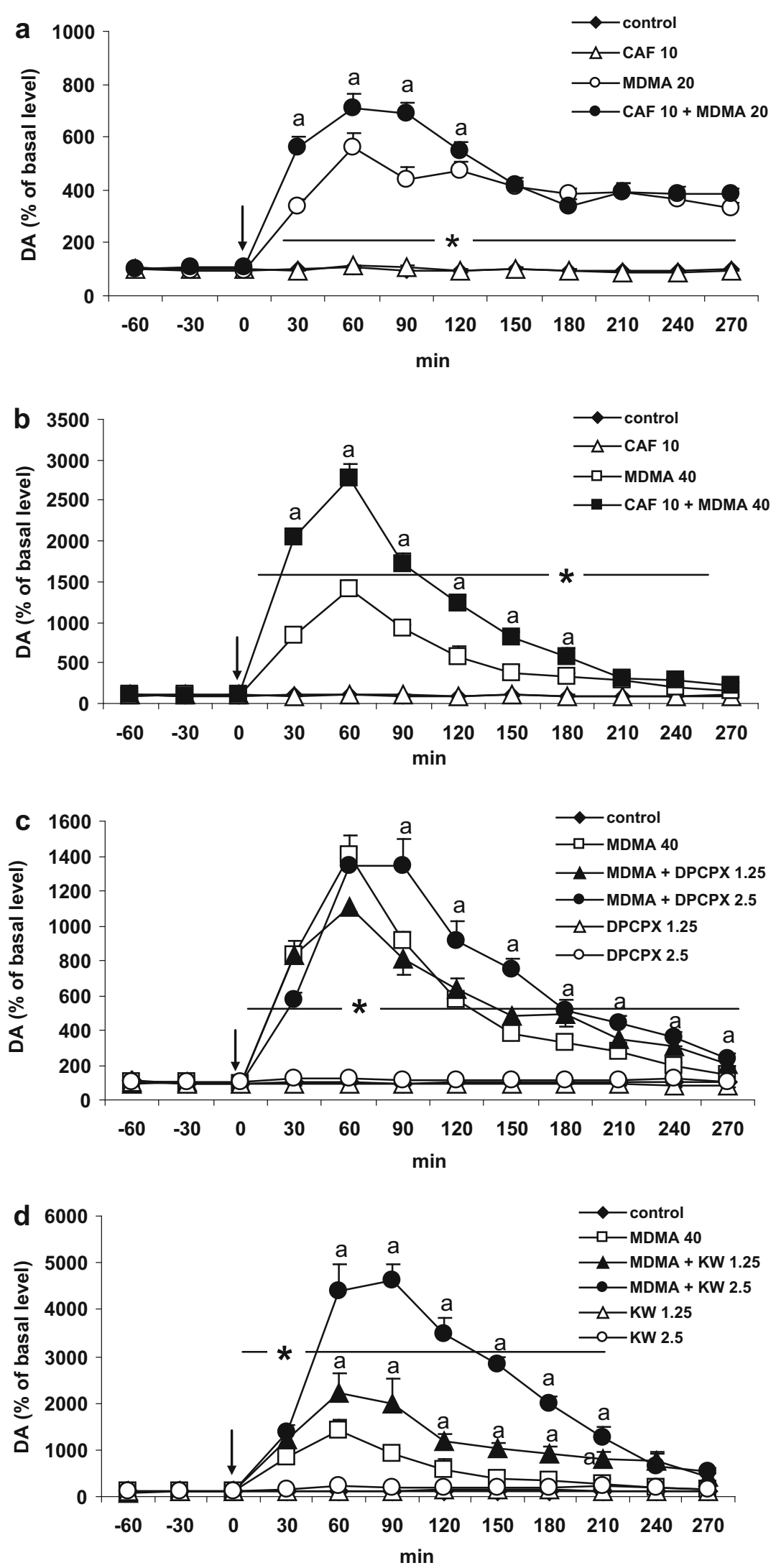
Fig. 2 The effect of caffeine (CAF) and adenosine A1 and A2A receptor antagonists, DPCPX and KW $6002(\mathrm{KW})$ on 5-HT release induced by MDMA in the mouse striatum. CAF (10 mg/kg), DPCPX (1.25 and $2.5 \mathrm{mg} / \mathrm{kg})$, and $\mathrm{KW}(1.25$ and $2.5 \mathrm{mg} / \mathrm{kg}$ ) were injected simultaneously with MDMA 20 or $40 \mathrm{mg} / \mathrm{kg}$ as indicated with an arrow. Values are the mean \pm SEM $(n=6-8$ animals). $* P<0.0001$ represents a significant difference in comparison to control group; " $a$ " $P<0.0002-0.01$ represents a significant difference in comparison to MDMA group (repeated measures ANOVA and Tukey's post-hoc test)
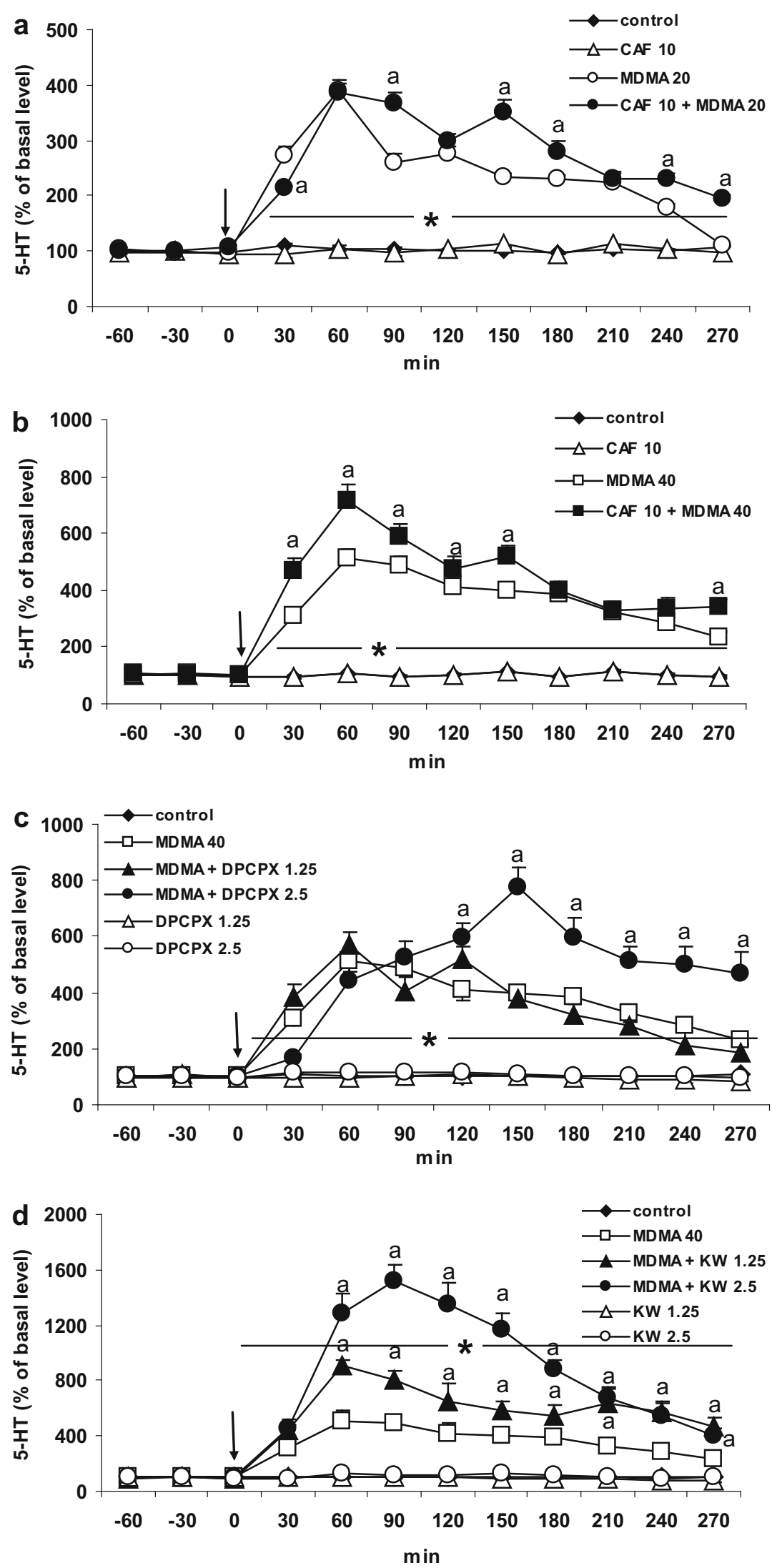
the interaction between treatment groups and sampling period $\left[F_{40,184}=45, P=0\right]$.

The selective adenosine A2A receptor antagonist KW 6002 at both doses of 1.25 and $2.5 \mathrm{mg} / \mathrm{kg}$ significantly $(P=0.0001)$ increased the effect of MDMA $(40 \mathrm{mg} / \mathrm{kg})$ on 5-HT release (Fig. 2d). Repeated measures ANOVA showed a significant effect of treatment groups $\left[F_{5,26}=236, \quad P=0\right], \quad$ sampling period $\left[F_{8,208}=80\right.$, $P=0]$, and the interaction between treatment groups and sampling period $\left[F_{40,208}=34, P=0\right]$. The basal extracellular 5-HT level in dialysates from the mouse striatum was $2.30 \pm 0.13(\mathrm{pg} / 10 \mu \mathrm{l}, n=99)$ and no significant differences between experimental groups were observed.

The Effect of Caffeine and Adenosine A1 and A2A Receptor Antagonists DPCPX and KW 6002 on MDMA-Induced Changes in Extracellular 3-MT Level in the Striatum of the Mouse

The level of the extraneuronal DA metabolite, 3-MT was significantly $(P=0.0001)$ increased by MDMA 20 and $40 \mathrm{mg} / \mathrm{kg}$ to ca. 711 and $1736 \%$ of the basal values, respectively, between 60 and $120 \mathrm{~min}$ after administration. Caffeine $(10 \mathrm{mg} / \mathrm{kg})$ significantly $(P=0.0002)$ increased the effect of a higher dose $(40 \mathrm{mg} / \mathrm{kg})$ of MDMA on 3-MT extracellular level, but did not affect the increase in 3-MT induced by a lower dose of MDMA (Fig. 3a, b). Repeated measures ANOVA showed a significant effect of treatment groups $\left[F_{5,25}=274, \quad P=0\right], \quad$ sampling period $\left[F_{8,200}=233, P=0\right]$, and the interaction between treatment groups and sampling period $\left[F_{40,200}=57, P=0\right]$.

The selective adenosine A1 receptor antagonist DPCPX at both doses, 1.25 and $2.5 \mathrm{mg} / \mathrm{kg}$ significantly ( $P=0.0001$ and $P=0.01$, respectively) increased the effect of MDMA $(40 \mathrm{mg} / \mathrm{kg})$ on extracellular 3-MT level (Fig. 3c). Repeated measures ANOVA showed a significant effect of treatment groups $\left[F_{5,24}=388, P=0\right]$, sampling period $\left[F_{8,192}=433, P=0\right]$, and the interaction between treatment groups and sampling period $\left[F_{40,192}=\right.$ $137, P=0]$.

The selective adenosine A2A receptor antagonist $\mathrm{KW}$ 6002 at both doses 1.25 and $2.5 \mathrm{mg} / \mathrm{kg}$ significantly $(P=0.0001)$ increased the effect of MDMA $(40 \mathrm{mg} / \mathrm{kg})$ on extracellular 3-MT level (Fig. 3d). Repeated measures ANOVA showed a significant effect of treatment groups $\left[F_{5,28}=556, P=0\right]$, sampling period $\left[F_{8,224}=215\right.$, $P=0]$, and the interaction between treatment groups and sampling period $\left[F_{40,224}=61, P=0\right]$. The basal extracellular 3-MT level in dialysates from the mouse striatum was $14.15 \pm 0.95(\mathrm{pg} / 10 \mu \mathrm{l}, n=102)$ and no significant differences between experimental groups were observed.
The Effect of Caffeine and Adenosine A1 and A2A Receptor Antagonists DPCPX and KW 6002 on MDMA-Induced Changes in Extracellular Level of DOPAC, HVA, and 5-HIAA in the Striatum of the Mouse

MDMA at doses of 20 and $40 \mathrm{mg} / \mathrm{kg}$ significantly $(P=0.0001)$ decreased the level of the intraneuronal metabolite of DA, DOPAC to ca. 14 and $9 \%$ of basal level at $120 \mathrm{~min}$ after administration. Caffeine at a dose of $10 \mathrm{mg} / \mathrm{kg}$ had no effect on the decrease in DOPAC level induced by both doses of MDMA (Fig. 4a). Repeated measures ANOVA of these data showed a statistically significant effect of treatment groups $\left[F_{5,29}=123, P=0\right]$, sampling period $\left[F_{8,232}=80\right.$, $P=0]$, and the interaction between treatment groups and sampling period $\left[F_{40,232}=9.7, P=0\right]$.

The selective adenosine A1 receptor antagonist DPCPX at both doses, 1.25 and $2.5 \mathrm{mg} / \mathrm{kg}$ did not affect the decrease in extracellular DOPAC level produced by MDMA $40 \mathrm{mg} / \mathrm{kg}$ (Fig. 5a). Repeated measures ANOVA of these data showed a statistically significant effect of treatment groups $\left[F_{3,15}=77, P=0\right]$, sampling period $\left[F_{8,120}=78, P=0\right]$, and the interaction between treatment groups and sampling period $\left[F_{24,120}=10.1, P=0\right]$. Similarly, the selective adenosine A2A receptor antagonist KW 6002 at both doses 1.25 and $2.5 \mathrm{mg} / \mathrm{kg}$ also did not influence the extracellular level of DOPAC decreased by MDMA (Fig. 5b). Repeated measures ANOVA of these data showed a statistically significant effect of treatment groups $\left[F_{3,19}=77, P=0\right]$, sampling period $\left[F_{8,152}=89\right.$, $P=0]$, and the interaction between treatment groups and sampling period $\left[F_{24,152}=8.78, P=0\right]$.

The extracellular level of HVA was significantly decreased by MDMA 20 and $40 \mathrm{mg} / \mathrm{kg} \quad(P=0.004$ and 0.0002 , respectively, in comparison to control group). Caffeine $(10 \mathrm{mg} / \mathrm{kg})$ did not change the effect of both doses of MDMA on the extracellular HVA level (Fig. 4b). Repeated measures ANOVA of these data showed a statistically significant effect of treatment groups $\left[F_{5,28}=11.2, P=0.0001\right]$, sampling period $\left[F_{8,224}=17.7, P=0\right]$, and the interaction between treatment groups and sampling period $\left[F_{40,224}=5.30\right.$, $P=0]$.

The adenosine A1 receptor antagonist DPCPX at doses of 1.25 and $2.5 \mathrm{mg} / \mathrm{kg}$ was without influence on the extracellular level of HVA decreased by MDMA (40 mg/ $\mathrm{kg}$ ) (Fig. 5c). Repeated measures ANOVA of these data showed a statistically significant effect of treatment groups $\left[F_{3,15}=12.2, P=0.003\right]$, sampling period $\left[F_{8,120}=31\right.$, $P=0]$, and the interaction between treatment groups and sampling period $\left[F_{24,120}=3.64, P=0.0001\right]$. Similarly, the selective adenosine A2A receptor antagonist KW 6002 at both doses 1.25 and $2.5 \mathrm{mg} / \mathrm{kg}$ also did not influence extracellular level of HVA decreased by MDMA (Fig. 5d). 
Fig. 3 The effect of caffeine (CAF) and adenosine A1 and A2A receptor antagonists, DPCPX and KW 6002 (KW) on extracellular level of 3-MT increased by MDMA in the mouse striatum. CAF $(10 \mathrm{mg} /$ $\mathrm{kg})$, DPCPX (1.25 and $2.5 \mathrm{mg}$ / $\mathrm{kg}$ ), and $\mathrm{KW}$ (1.25 and $2.5 \mathrm{mg}$ / $\mathrm{kg}$ ) were injected simultaneously with MDMA 20 or $40 \mathrm{mg} / \mathrm{kg}$ as indicated with an arrow. Values are the mean \pm SEM $(n=6-8$ animals). ${ }^{*} P<0.0001$ represents a significant difference in comparison to control group; " $a$ " $P<0.0002$ represents a significant difference in comparison to MDMA group (repeated measures ANOVA and Tukey's post-hoc test)
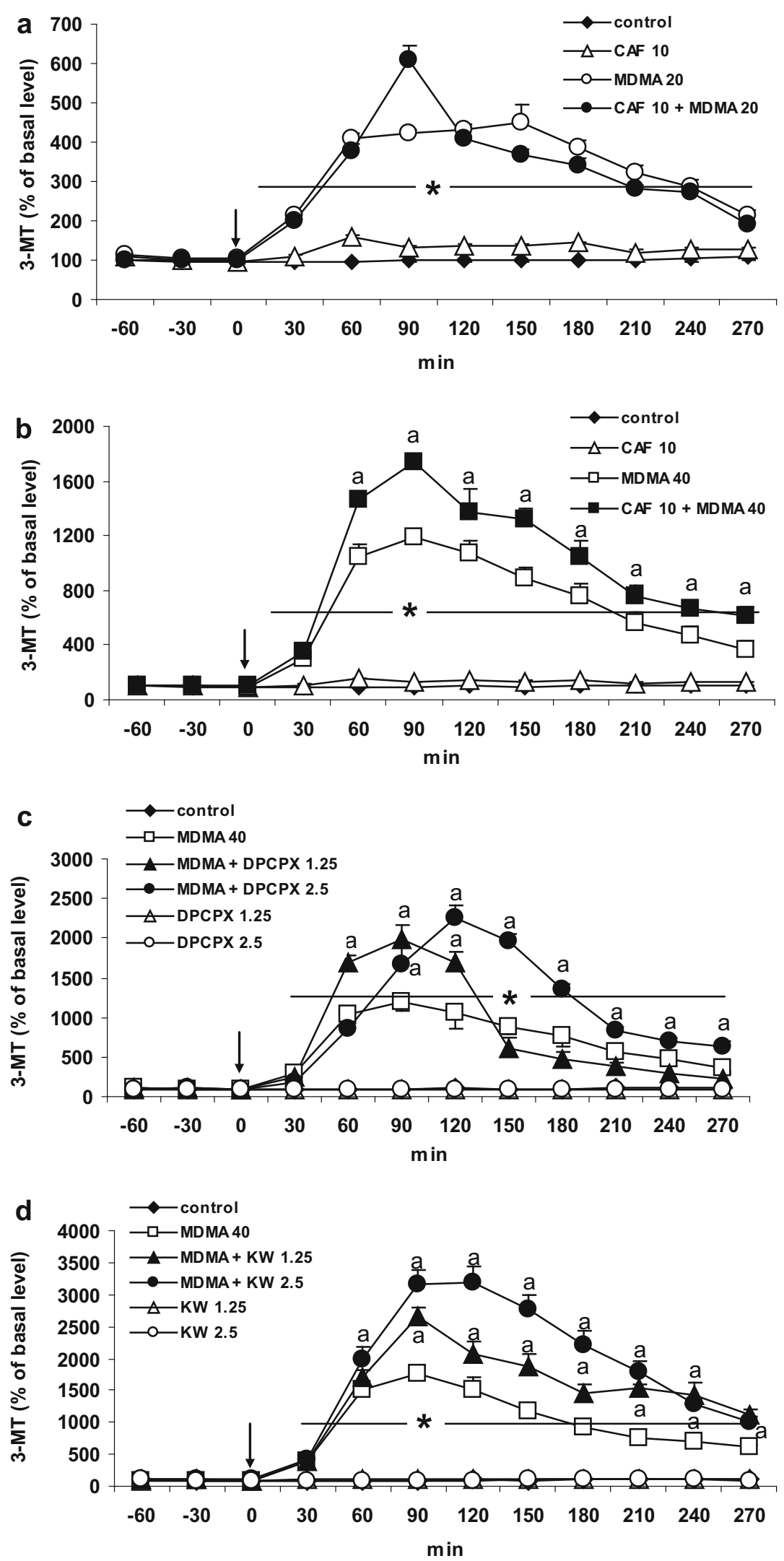
Fig. 4 The effect of caffeine (CAF) on changes in extracellular level of DOPAC, HVA, and 5-HIAA induced by MDMA in the mouse striatum. CAF $(10 \mathrm{mg} / \mathrm{kg})$ was injected simultaneously with MDMA 20 or $40 \mathrm{mg} / \mathrm{kg}$ as indicated with an arrow. Values are the mean \pm SEM $(n=6-8$ animals). $* P<0.0001$ represents a significant difference in comparison to control group (repeated measures ANOVA and Tukey's post-hoc test)
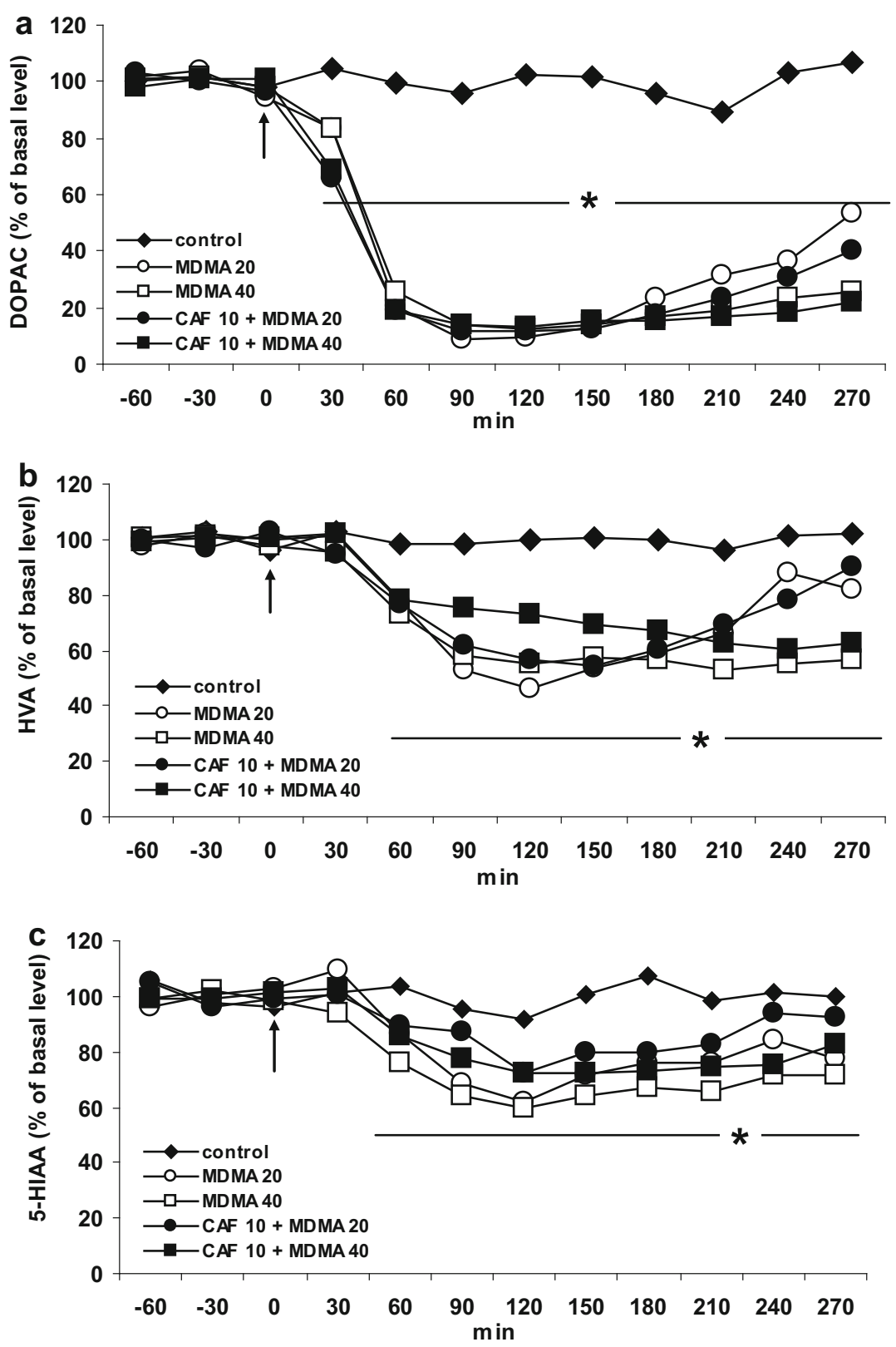

Repeated measures ANOVA of these data showed a statistically significant effect of treatment groups $\left[F_{3,19}=7.37, P=0.002\right]$, sampling period $\left[F_{8,152}=5.7\right.$, $P=0.0001]$, and the interaction between treatment groups and sampling period $\left[F_{24,152}=2.19, P=0.002\right]$.

MDMA in a dose of $40 \mathrm{mg} / \mathrm{kg}$ but not in the lower one $20 \mathrm{mg} / \mathrm{kg}$ significantly decreased extracellular level of serotonin metabolite, 5-HIAA $(P=0.008$ in comparison to control group). Caffeine $(10 \mathrm{mg} / \mathrm{kg})$ had no effect on this decrease (Fig. 4c). Repeated measures ANOVA of these data showed a statistically significant effect of treatment groups $\left[F_{5,28}=5.5, P=0.001\right]$, sampling period $\left[F_{8,224}=7.5, \quad P=0.0001\right]$, and the interaction between treatment groups and sampling period $\left[F_{40,224}=\right.$ 2.54, $P=0.0001]$.

The adenosine A1 receptor antagonist DPCPX at a dose of $2.5 \mathrm{mg} / \mathrm{kg}$ but not at a lower one $(1.25 \mathrm{mg} / \mathrm{kg})$ reversed the effect of MDMA (40 mg/kg) on the extracellular 5-HIAA level $(P=0.03$, Fig. 5c). Repeated measures ANOVA of these data showed a statistically significant effect of treatment groups $\left[F_{3,15}=15.1, P=0.0001\right]$, sampling period $\left[F_{8,120}=4.34, P=0.0001\right]$, and the interaction between treatment groups and sampling period $\left[F_{24,120}=3.18, P=0.0001\right]$. The decrease in extracellular 5-HIAA level produced by MDMA $40 \mathrm{mg} / \mathrm{kg}$ was also counteracted by a higher dose $(2.5 \mathrm{mg} / \mathrm{kg})$ of the adenosine 

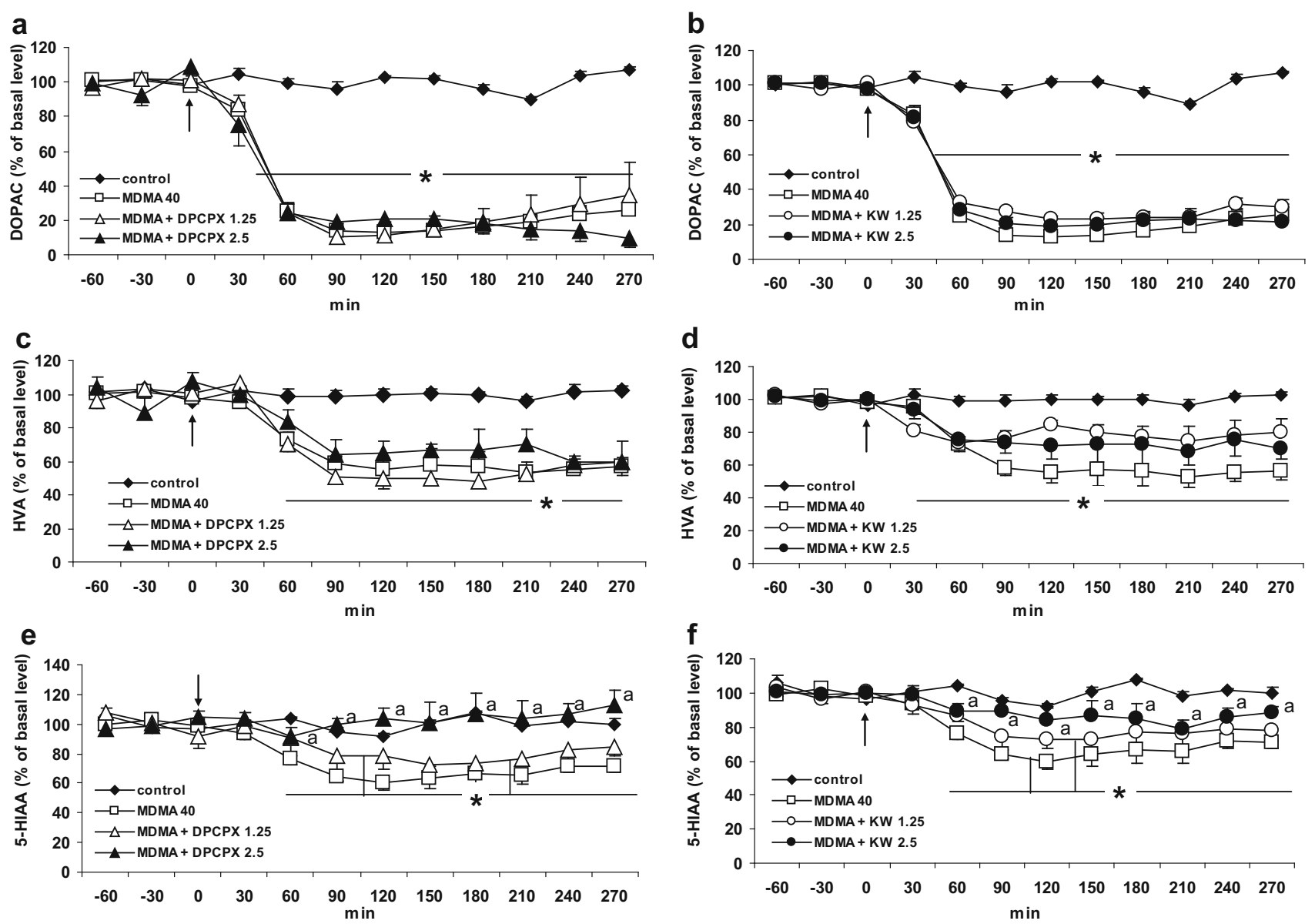

Fig. 5 The effect of adenosine A1 and A2A receptor antagonists, DPCPX and KW $6002(\mathrm{KW})$ on the changes in extracellular level of DOPAC, HVA, and 5-HIAA induced by MDMA in the mouse striatum. DPCPX (1.25 and $2.5 \mathrm{mg} / \mathrm{kg})$ and $\mathrm{KW}(1.25$ and $2.5 \mathrm{mg} / \mathrm{kg}$ ) were injected simultaneously with MDMA $40 \mathrm{mg} / \mathrm{kg}$ as indicated

A2A receptor antagonist KW $6002(P=0.0003$, Fig. 5f). Repeated measures ANOVA of these data showed a statistically significant effect of treatment groups $\left[F_{3,19}=\right.$ $6.2, P=0.004]$, sampling period $\left[F_{8,152}=8.21, P=0\right]$, but there were no interactions between treatment groups and sampling period $\left[F_{24,152}=1.22, P=0.24\right]$.

The basal extracellular levels of DOPAC, HVA, and 5-HIAA (in $\mathrm{pg} / 10 \mu \mathrm{l}, \quad n=183$ ) were $1470 \pm 148$, $1350 \pm 166$, and $342 \pm 30$, respectively, and no significant differences between experimental groups were observed.

The Effect of Caffeine and Adenosine A1 and A2A Receptor Antagonists DPCPX and KW 6002 on Extracellular Level of DA, 5-HT, 3-MT, DOPAC, HVA, and 5-HIAA in the Striatum of the Mouse

Caffeine $(10 \mathrm{mg} / \mathrm{kg})$ and the adenosine A1 receptor antagonist DPCPX at a lower dose $(1.25 \mathrm{mg} / \mathrm{kg})$ given alone were

with an arrow. Values are the mean \pm SEM ( $n=6-8$ animals). $* P<0.01-0.0002$ represents a significant difference in comparison to control group; " $a$ " $P<0.03-0.0003$ represents a significant difference in comparison to MDMA group (repeated measures ANOVA and Tukey's post-hoc test)

without effect on extracellular level of DA in the mouse striatum (Fig. 6a). However, the adenosine A2A receptor antagonist KW 6002 at both doses (1.25 and $2.5 \mathrm{mg} / \mathrm{kg})$ and the adenosine A1 receptor antagonist DPCPX at a higher dose of $2.5 \mathrm{mg} / \mathrm{kg}$ significantly increased extracellular DA level $(P=0.0001$ and $P=0.001$, respectively, Fig. 6a). Repeated measures ANOVA of these data showed a statistically significant effect of treatment groups $\left[F_{5,21}=357\right.$, $P=0]$, sampling period $\left[F_{8,168}=11.2, P=0\right]$, and the interaction between treatment groups and sampling period $\left[F_{40,168}=5.43, P=0\right]$.

Extracellular serotonin level was not changed by caffeine but was increased by higher doses $(2.5 \mathrm{mg} / \mathrm{kg})$ of the adenosine $\mathrm{A} 1$ and $\mathrm{A} 2 \mathrm{~A}$ receptor antagonists, DPCPX and KW 6002 (Fig. 6b). Repeated measures ANOVA of these data showed no significant effect of treatment groups $\left[F_{5,18}=19.87, P=0.0001\right]$, sampling period $\left[F_{8,144}=\right.$ $8.54, P=0]$, and the interaction between treatment groups and sampling period $\left[F_{40,144}=2.76, P=0.0001\right]$. 

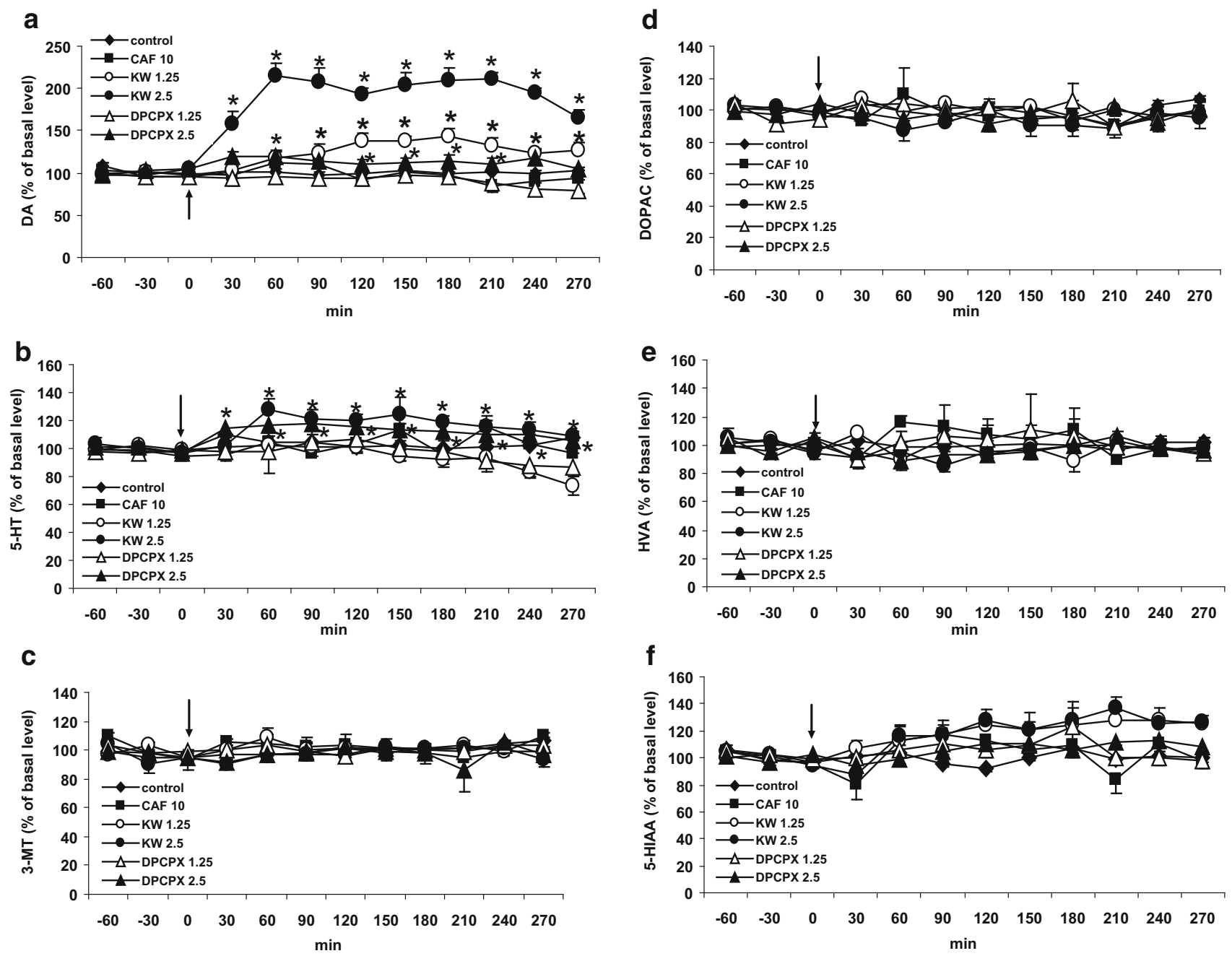

Fig. 6 The effect of caffeine (CAF) and adenosine A1 and A2A receptor antagonists, DPCPX and KW $6002(\mathrm{KW})$ on extracellular level of DA, 5-HT, 3-MT, DOPAC, HVA, and 5-HIAA in the mouse striatum. CAF (10 mg/kg), DPCPX (1.25 and $2.5 \mathrm{mg} / \mathrm{kg})$, and $\mathrm{KW}$

The level of the extraneuronal DA metabolite, 3-MT was not affected by caffeine and adenosine $\mathrm{A} 1$ and $\mathrm{A} 2 \mathrm{~A}$ receptor antagonists when given alone (Fig. 6c). Repeated measures ANOVA of these data showed a statistically nonsignificant effect of treatment groups $\left[F_{5,19}=0.69\right.$, $P=0.64]$, sampling period $\left[F_{8,152}=1.10, P=0.36\right]$, and the interaction between treatment groups and sampling period $\left[F_{40,152}=1.07, P=0.37\right]$.

The extracellular level of DOPAC was not changed either by caffeine or the adenosine $\mathrm{A} 1$ and $\mathrm{A} 2 \mathrm{~A}$ receptor antagonists DPCPX and KW 6002, respectively (Fig. 6d). Repeated measures ANOVA of these data showed no significant effect of treatment groups $\left[F_{5,19}=0.60, P=0.7\right]$, sampling period $\left[F_{8,152}=0.66, P=0.73\right]$, and the interaction between treatment groups and sampling period $\left[F_{40,152}=0.89, P=0.66\right]$.

$(1.25$ and $2.5 \mathrm{mg} / \mathrm{kg}$ ) were injected as indicated with an arrow. Values are the mean $\pm \operatorname{SEM}(n=6-8$ animals $) * P<0.05-0.0002$ represents a significant difference in comparison to control group (repeated measures ANOVA and Tukey's post-hoc test)

Similarly, the final catecholamine metabolite, HVA was also not affected by caffeine and the adenosine A1 and A2A receptor antagonists DPCPX and KW 6002, respectively (Fig. 6e). Repeated measures ANOVA of these data showed no significant effect of treatment groups $\left[F_{5,19}=0.24, P=0.94\right]$, sampling period $\left[F_{8,152}=0.58\right.$, $P=0.79]$, and the interaction between treatment groups and sampling period $\left[F_{40,152}=1.13, P=0.3\right]$.

Caffeine and the adenosine $\mathrm{A} 1$ and $\mathrm{A} 2 \mathrm{~A}$ receptor antagonists DPCPX and KW 6002 did not influence the extracellular level of the serotonin metabolite, 5-HIAA (Fig. 6f). Repeated measures ANOVA of these data showed no significant effect of treatment groups $\left[F_{5,19}=1.31, P=0.3\right]$, sampling period $\left[F_{8,152}=1.89\right.$, $P=0.06]$, and the interaction between treatment groups and sampling period $\left[F_{40,152}=1.38, P=0.09\right]$. 

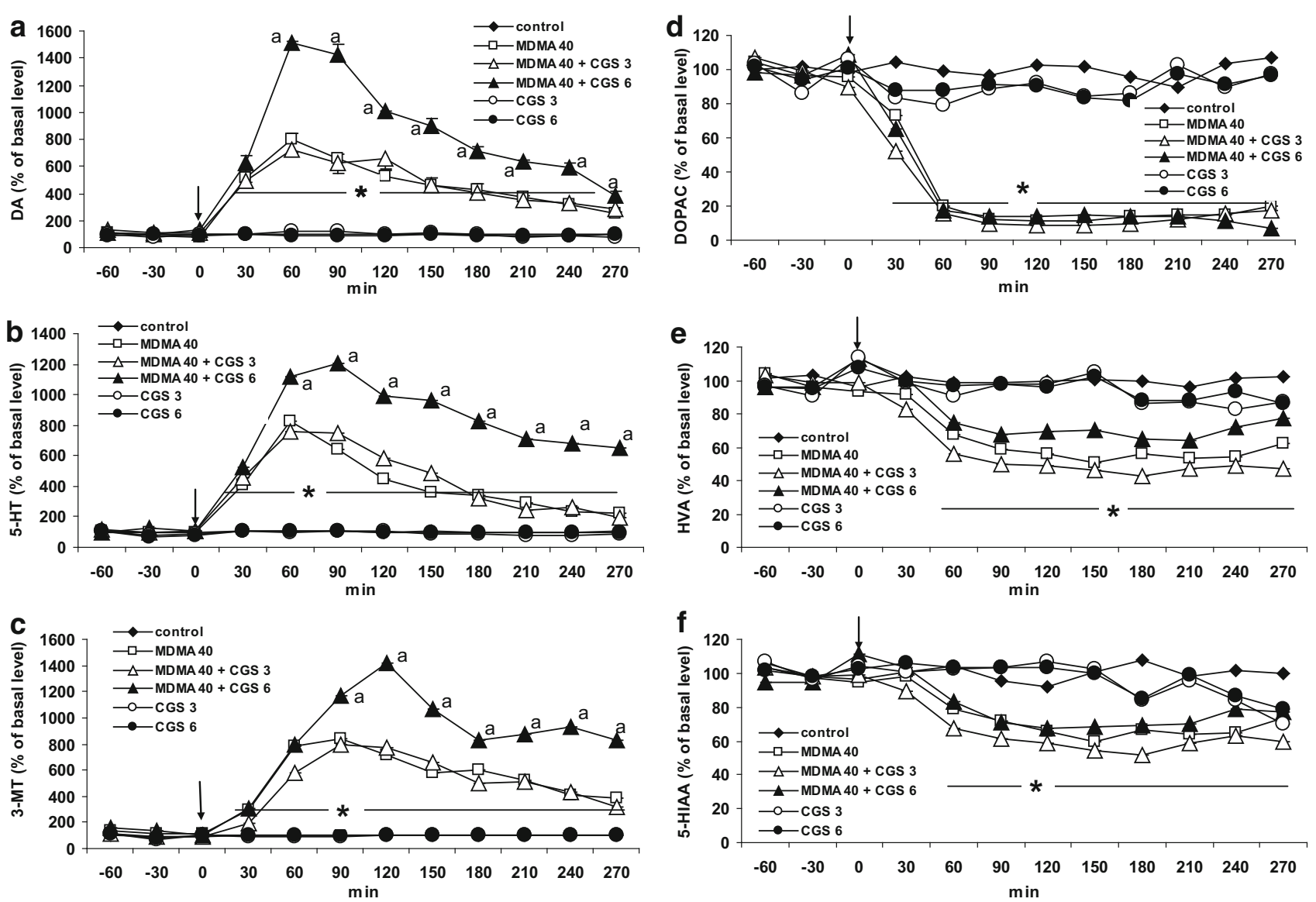

Fig. 7 The effect of the adenosine A1/A2A receptor antagonist CGS 15943A (CGS) on MDMA-induced changes in extracellular level of DA, 5-HT, 3-MT, DOPAC, HVA, and 5-HIAA in the mouse striatum. CGS 15943A (3 and $6 \mathrm{mg} / \mathrm{kg}$ ) was injected simultaneously with MDMA $40 \mathrm{mg} / \mathrm{kg}$ as indicated with an arrow. Values are the

mean $\pm \operatorname{SEM}(n=4$ animals). $* P<0.01-0.0002$ represents significant difference in comparison to control group; " $a$ " $P<0.02-0.0002$ represents a significant difference in comparison to MDMA group (repeated measures ANOVA and Tukey's post-hoc test)

The basal extracellular levels of DA, 5-HT, 3-MT, DOPAC, HVA, and 5-HIAA (in pg/10 $\mu \mathrm{l}, n=78$ ) were $7.6 \pm 0.62$, $2.1 \pm 0.23,12.7 \pm 1.18,1493 \pm 140,1632 \pm 150$, and $388 \pm 42$, respectively, and no significant differences between experimental groups were observed.

The Effect of Adenosine A1/A2A Receptor Antagonist CGS 15943A on MDMA-Induced Changes in Extracellular Level of DA, 5-HT, 3-MT, DOPAC, HVA, and 5-HIAA in the Striatum of the Mouse

The non-selective A1/A2A adenosine receptor antagonist, CGS $15943 \mathrm{~A}$ at a dose of $6 \mathrm{mg} / \mathrm{kg}$ but not at the lower one (3 mg/kg) significantly $(P=0.0002)$ enhanced the increase in striatal DA release induced by MDMA (Fig. 7a). Repeated measures ANOVA of these data showed a significant effect of treatment groups $\left[F_{5,20}=155, P=0\right]$, sampling period $\left[F_{8,160}=87, P=0\right]$, and the interaction between treatment groups and sampling period $\left[F_{40,160}=24\right.$,

$P=0$ ]. Similarly, CGS 15943A at a higher dose increased 5-HT release ( $P=0.0002$ ) produced by MDMA (Fig. 7b). Repeated measures ANOVA of these data showed a significant effect of treatment groups $\left[F_{5,20}=156, P=0\right]$, sampling period $\left[F_{8,160}=77, P=0\right]$, and the interaction between treatment groups and sampling period $\left[F_{40,160}=19, P=0\right]$. The increase in the extraneuronal DA metabolite level, 3-MT was enhanced by CGS 15943A at a dose of $6 \mathrm{mg} / \mathrm{kg}$ (Fig. 7c). Repeated measures ANOVA of these data showed a significant effect of treatment groups $\left[F_{5,20}=173, \quad P=0\right], \quad$ sampling period $\left[F_{8,160}=38\right.$, $P=0]$, and the interaction between treatment groups and sampling period $\left[F_{40,160}=11, P=0\right]$. The level of the intraneuronal metabolite of DA, DOPAC decreased by MDMA was not affected by both doses of CGS 15943A (Fig. 7d). Repeated measures ANOVA of these data showed a significant effect of treatment groups $\left[F_{5,20}=121\right.$, $P=0]$, sampling period $\left[F_{8,160}=38, P=0\right]$, and the interaction between treatment groups and sampling period 
$\left[F_{40,160}=11, P=0\right]$. The decrease in HVA induced by MDMA was not affected by CGS 15943A (Fig. 7e). Repeated measures ANOVA of these data showed a significant effect of treatment groups $\left[F_{5,20}=5.92, P=0.002\right]$, sampling period $\left[F_{8,160}=12.4, P=0\right]$, and the interaction between treatment groups and sampling period $\left[F_{40,160}=2.12, \quad P=0.001\right]$. The serotonin metabolite, 5-HIAA was decreased by MDMA, but its effect was not changed by CGS 15943A (Fig. 7f). Repeated measures ANOVA of these data showed a significant effect of treatment groups $\left[F_{5,20}=7.06, P=0.002\right]$, sampling period $\left[F_{8,160}=19.6, P=0\right]$, and the interaction between treatment groups and sampling period $\left[F_{40,160}=3.68, P=0\right]$. CGS 15943A given alone did not influence the extracellular level of DA, 5-HT, 3-MT, DOPAC, HVA, and 5-HIAA in the mouse striatum (Fig. 7a-f).

The basal extracellular levels of DA, 5-HT, 3-MT, DOPAC, HVA, and 5-HIAA in this experiment were (in $\mathrm{pg} / 10 \mu \mathrm{l}, n=78) 8.14 \pm 1.1,2.41 \pm 0.45,12.65 \pm 1.64$, $1615 \pm 152,1299 \pm 119$, and $337 \pm 40$, respectively. We did not observe significant differences between experimental groups in the basal levels of neurotransmitters and their metabolites.

\section{Discussion}

The findings of our in vivo study showed that MDMA increased DA and 5-HT release in a dose-dependent manner in the mouse striatum. However, the effect of MDMA on 5-HT release was weaker than that on DA release which does not correspond to the rank order of potency for MDMA inhibition of the DA and 5-HT uptake in vitro, where MDMA exhibited a higher potency at serotonin transporter (SERT) than at dopamine transporter (DAT) (Han and Gu 2006). However, it has to be noted that MDMA has the ability to directly bind to a number of classical neurotransmitter receptors which may contribute to a stronger MDMA effect on DA release. For instance, MDMA by acting directly at brain nicotinic acetylcholine receptors may increase striatal DA release (Faure et al. 2014). In addition, after acute administration of MDMA, DA release may be increased by activation of specific 5-HT receptors. 5-HT2A receptors densely localized on glutamatergic cells in the frontal cortex and activated by the released 5-HT may elicit an increase in glutamate level leading to a rise in DA release in an indirect way (Alex and Pehek 2007). Furthermore, MDMA may suppress nigral GABA release following 5-HT2A/2C receptor activation thus causing disinhibition of the striatal DA neurons ( $\mathrm{Gu}-$ delsky and Yamamoto 2008). The MDMA effect may be additionally strengthened by its major metabolite, 3,4methylenedioxyamphetamine (MDA) having a higher activity at DAT than at SERT, thereby slightly more increasing DA release than 5-HT (Baumann et al. 2007).

In our study, caffeine alone at a dose of $10 \mathrm{mg} / \mathrm{kg}$ failed to alter DA and 5-HT release in the mouse striatum. However, co-administration of caffeine and MDMA had a stronger effect on DA and 5-HT release than that of MDMA alone. It was evidenced that caffeine at doses between 10 and $40 \mathrm{mg} / \mathrm{kg}$ increased spontaneous locomotion in mice and rats (Garret and Holtzman 1994; Nikodijeviç et al. 1993). On the other hand, caffeine has been reported to increase DA turnover only at high doses in a manner unrelated to the locomotor stimulation (Morgan and Vestal 1989). Ikeda et al. (2011) reported enhancement of DA release in the striatum of anesthetized rats after concomitant administration of caffeine $(20 \mathrm{mg} / \mathrm{kg})$ and MDMA $(10 \mathrm{mg} / \mathrm{kg})$. These data are in line with our findings showing in vivo synergistic interaction between caffeine and MDMA in the mouse striatum. The pharmacokinetic interactions have also to be considered in the mechanisms mediating the ability of caffeine to promote MDMA-induced DA release. MDMA and caffeine are metabolized in rodents by the same enzyme, CYP1A2 (Singh et al. 2009). Thus competitive interactions between MDMA and caffeine at CYP1A2 may underlie the mechanism of caffeine/MDMA interaction in their effect on DA as well as 5-HT release. However, MDMA-induced DA and 5-HT release may be also regulated by adenosine receptors as shown in other studies in which agonists of adenosine $\mathrm{A} 1$ and $\mathrm{A} 2 \mathrm{~A}$ receptors decreased methamphetamine-induced DA release or $\mathrm{KCl}$-evoked DA and glutamate release in the rat striatum (Golembiowska and Żylewska 1997, 1998) and in behavioral studies in which the adenosine A2A agonist CGS 21680 provided a partial protection against MDMA-induced deficit in spatial learning and hippocampal cell death (Kermanian et al. 2012). Caffeine as a non-selective antagonist of adenosine $\mathrm{A} 1$ and $\mathrm{A} 2 \mathrm{~A}$ receptors with in vitro affinity in $\mu \mathrm{M}$ range (Fredholm et al. 1999) may increase DA and glutamate in the striatum via blockade of inhibitory presynaptic adenosine A1 receptors (Borycz et al. 2007; Ciruela et al. 2006; Okada et al. 1996). Similarly, adenosine A1 receptor blockade was shown to increase hippocampal 5-HT release (Okada et al. 1999). A greater response in terms of DA release was observed in the striatal tissue slices superfused with MDMA in combination with caffeine than that obtained following the application of each of the drugs alone (Vanattou-Saïfoudine et al. 2011). Our results show for the first time the effect of the combined treatment of caffeine and MDMA not only on DA but also on 5-HT release as measured by an in vivo microdialysis in mice. We present the evidence that adenosine $\mathrm{A} 1$ and $\mathrm{A} 2 \mathrm{~A}$ receptors are involved in this effect by showing that the 
selective antagonists of $\mathrm{A} 1$ and $\mathrm{A} 2 \mathrm{~A}$ adenosine receptors, DPCPX and KW 6002 were able to mimic the effect of caffeine. Both adenosine receptor antagonists markedly enhanced MDMA-induced DA and 5-HT release in the mouse striatum, but the potency of their effect was different. The effect of KW 6002 at a lower dose $(1.25 \mathrm{mg} /$ $\mathrm{kg}$ ) was similar to the effect of caffeine co-administered with MDMA $40 \mathrm{mg} / \mathrm{kg}$. However, the effect of a higher dose of KW $6002(2.5 \mathrm{mg} / \mathrm{kg})$ was much stronger on either DA or 5-HT release than that of caffeine co-administered with MDMA $40 \mathrm{mg} / \mathrm{kg}$. In turn, the effect of the A1 receptor antagonist, DPCPX given at a higher dose $(2.5 \mathrm{mg} / \mathrm{kg})$ with MDMA on DA release was weaker in comparison to the effect of combined administration of MDMA with caffeine or a lower dose of KW 6002. Nevertheless, the difference between the group treated with DPCPX $(2.5 \mathrm{mg} / \mathrm{kg})$ jointly with MDMA was significant in comparison to MDMA alone. A similar tendency was observed in DPCPX action on 5-HT release. These results indicate that $\mathrm{A} 2 \mathrm{~A}$ rather than $\mathrm{A} 1$ receptor blockade plays a greater role in the potentiating MDMA effect on DA and 5-HT release. One can argue that adenosine receptor antagonists used in this study differ in occupancy of adenosine receptors. However, both KW 6002 and DPCPX show affinity for respective adenosine receptors in a low nM range (Jacobson and Van Rhee 1997; Saki et al. 2013). In our study, both drugs were used in their active doses as evidenced by other tests. DPCPX at doses of $1.25-5 \mathrm{mg} / \mathrm{kg}$ increased motility and locomotion in mice (Kuzmin et al. 2006). KW 6002 at doses of $2.5-3 \mathrm{mg} / \mathrm{kg}$ increased locomotor activity in mice (Aoyama et al. 2000; Yu et al. 2008) with similar potency to that of caffeine at a dose of $10 \mathrm{mg} /$ $\mathrm{kg}$. Interestingly, our findings showed that KW 6002 and DPCPX alone (but not caffeine) increased the basal extracellular level of DA and 5-HT. These data indicate that DA and 5-HT nerve terminals are under tonic influence of adenosine $\mathrm{A} 1$ and $\mathrm{A} 2 \mathrm{~A}$ receptors. The question arises what mechanism mediates the control of MDMA-induced DA and 5-HT release in the mouse striatum by adenosine receptor blockade. It is known that striatal adenosine A1 receptors have presynaptic and postsynaptic location, and acting as presynaptic heteroreceptors they may modulate neurotransmitter release from DA or 5-HT terminals (Ferré et al. 1997; Vanattou-Saïfoudine et al. 2011). Striatal adenosine $\mathrm{A} 2 \mathrm{~A}$ receptors are mostly postsynaptic and are highly expressed in striatopallidal GABAergic neurons, where they antagonistically interact with dopamine D2 receptors (Ferré et al. 1997). In addition, they are localized in striatal glutamatergic terminals where they are involved in the modulation of glutamate release (Ciruela et al. 2006). The lack of A2A receptors on striatal DA or 5-HT terminals suggests that the involvement of $\mathrm{A} 2 \mathrm{~A}$ receptors in the mechanism of DA or 5-HT release may be secondary and related to the changes in the activity of striatal output pathways elicited by A2A postsynaptic receptors, possibly by their negative interaction with dopamine $\mathrm{D} 2$ receptors. In fact, there is evidence that peripheral but not local administration of adenosine A2A antagonists increases extracellular concentration of DA in the striatum of naive rats (Gołembiowska et al. 2009; Gołembiowska and Żylewska 1997; Okada et al. 1996). Moreover, behavioral studies indicate that rather A2A than A1 adenosine receptors seem to be involved in the effects of caffeine. Lazarus et al. (2011) using selective gene deletion strategies demonstrated that $\mathrm{A} 2 \mathrm{~A}$ receptors in the shell region of the nucleus accumbens were responsible for the effect of caffeine on wakefulness. Another study using also genetic knockout models showed that A2A adenosine receptors were required for psychomotor stimulant effect of caffeine in mice (Chen et al. 2010).

Primary action of caffeine seems to be exerted through adenosine $\mathrm{A} 1$ and $\mathrm{A} 2 \mathrm{~A}$ receptors since these receptors bind caffeine at low concentrations (Fredholm et al. 1999). However, caffeine at a dose of $6.25 \mathrm{mg} / \mathrm{kg}$ which is known to induce its stimulant motor effects was shown to occupy $66 \%$ of striatal adenosine $\mathrm{A} 2 \mathrm{~A}$ receptors and further increase in its dose would lead to $55 \%$ occupancy of cortical A1 receptors (Yacoubi et al. 2001). It has to be taken into consideration that caffeine in a dose of $10 \mathrm{mg} / \mathrm{kg}$ used in our study in which it significantly increased MDMA-induced DA and 5-HT release may also exert its effect via blockade of adenosine A3 receptor. Caffeine has a low in vitro affinity for A3 receptor (Fredholm et al. 2001). However, under conditions of nearly maximal occupancy of A2A and A1 receptors, adenosine A3 receptor may be responsible for caffeine stimulatory action. A reduction in caffeine-induced stimulation of motor activity in A3R KO mice corroborates this suggestion (Björklund et al. 2008). In spite of a low density of A3 receptors in the brain (Linden 1994) and their ca. 100 fold lower affinity for adenosine in comparison to A1 and A2A receptors (Jacobson and Van Rhee 1997) A3 receptors may be activated under pathological conditions (e.g., ischemia) when adenosine concentration is increased (Chen et al. 2006). However, this is not a case in our study since we did not observe increased adenosine extracellular level after administration of MDMA into mice (results not shown). Therefore, rather $\mathrm{A} 1$ and $\mathrm{A} 2 \mathrm{~A}$ but not $\mathrm{A} 3$ adenosine receptors seem to be engaged in the potentiating effect of caffeine on DA and 5-HT release in the mouse striatum.

Another possibility which may explain the effect of caffeine and A2A receptor antagonists on DA and 5-HT release under basal and stimulated conditions is their effect on metabolism of these monoamines. KW 6002 and 


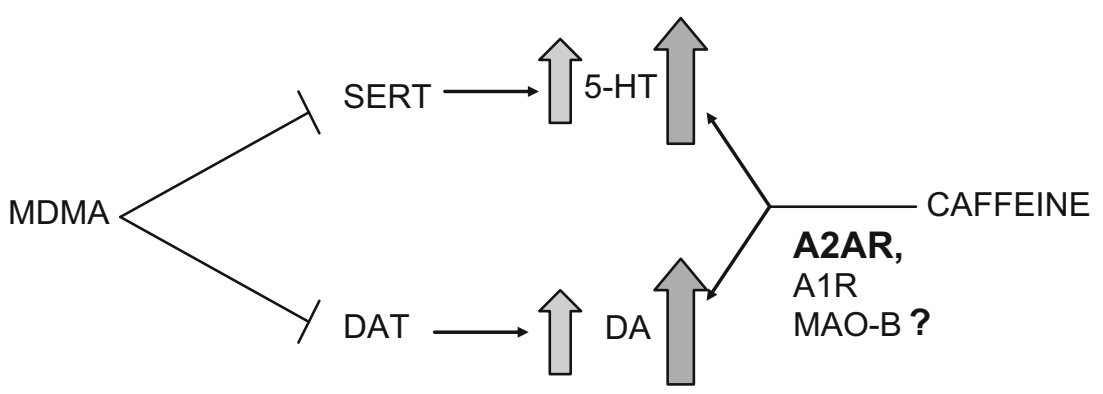

Fig. 8 Diagram showing a summary and conclusion of the presented findings. MDMA by blocking 5-HT transporter (SERT) and DA transporter (DAT) produces an increase in extracellular level of 5-HT and DA. Caffeine enhances the effect of MDMA on 5-HT and DA by

caffeine represent the class of methylxanthine A2A antagonists which are competitive monoamine oxidase-B (MAO-B) inhibitors (Castagnoli et al. 2003). Thus, methylxanthine A2A antagonists by slowing down cytosolic monoamine utilization and their conversion to DOPAC or 5-HIAA may increase the synaptic level of DA or 5-HT. This effect may be particularly important in the presence of MDMA, thereby increasing the extravesicular monoamine neurotransmitters inside nerve endings which are mainly metabolized by MAO (Sprague et al. 1998). In our study, we observed a decrease in extracellular level of DOPAC, homovanillic acid (HVA), and 5-hydroxyindoleacetic acid (5-HIAA) resulting from the inhibition of DAT or SERT by MDMA. Caffeine or KW 6002 as methylxanthine MAO-B inhibitors should slow down monoamine transformation into DOPAC and HVA, thus additionally causing the decrease in extracellular level of these metabolites. However, in our study, no differences were found in groups treated with the combination of MDMA and KW 6002 or caffeine in comparison to MDMA alone. This may suggest that the effect on MAO-B inhibition by caffeine or KW 6002 is negligible or it is masked by rapid removal of DA from cytosolic compartment and its metabolism in the synaptic cleft. The latter possibility is confirmed by the fact that KW 6002 which inhibits MAO-B with Ki value in $\mu \mathrm{M}$ range (Petzer et al. 2003), but not caffeine which inhibits MAO-B in mM range (Petzer et al. 2013), increased the extracellular DA level when given alone in mice. Interestingly, KW 6002 and DPCPX reversed to control values of the extracellular level of 5-HIAA decreased by MDMA. As serotonin is the substrate for MAO-A isoform (Youdim et al. 2006), increase in extracellular 5-HIAA level may rather result from the stimulation of 5-HT synthesis by these antagonists in the presence of MDMA.

In order to resolve whether the effect of caffeine on MDMA-induced DA and 5-HT release in the mouse striatum is mediated via postsynaptic adenosine $\mathrm{A} 2 \mathrm{~A}$ receptors but not by MAO inhibition, we tested if the nonxanthine adenosine receptor antagonist CGS 15943A lacking MAO-B blocking mainly adenosine $\mathrm{A} 2 \mathrm{~A}$ receptors and to a smaller extent adenosine A1 receptors. There is no evidence for the role of MAO-B inhibition by caffeine in its effect on monoamine release

activity (Castagnoli et al. 2003) increases, like caffeine and KW 6002, DA and 5-HT release. CGS 15943A is a potent adenosine receptor antagonist with seven-fold greater selectivity for A2A receptor versus A1 receptor, and an IC50 of 3 $\mathrm{nM}$ at the A2A receptor (Francis et al. 1988). When used in our study in pharmacologically effective doses (Czuczwar et al. 1991; Griebel et al. 1991), it enhanced MDMA effect on DA and 5-HT release. We also did not observe differences in extracellular level of DOPAC, HVA, and 5-HIAA in groups treated with MDMA alone and its combination with CGS 15943A. These findings suggest that the caffeine effect on MDMA-induced DA and 5-HT release in the mouse striatum is linked to its action on A2A adenosine receptors and is rather not related to the modification of MAO activity.

Interestingly, co-treatment of MDMA and caffeine or adenosine receptor antagonists markedly increased extracellular level of 3-methoxytyramine (3-MT), another metabolite of DA. 3-MT as a product of catabolic enzyme catechol-O-methyltransferase (EC 2.1.1.6; COMT) activity is a good indicator of extraneuronal metabolism of DA released into synaptic cleft. The increase in 3-MT level induced by caffeine or adenosine receptor antagonists coadministered with MDMA suggests that these drugs prolonged DA clearance from extracellular space resulting in a greater sustained extraneuronal DA level. These data strongly indicate that the enhancement of astroglia and microglia reactivity by caffeine (Khairnar et al. 2010) or neuroinflammation (Costa et al. 2014) may be due to an increase in DA release, excessive oxidative stress or formation of serotonergic toxins (Gołembiowska et al. 2009; Gołembiowska and Dziubina 2012; Schmitt and Reith 2010) which all lead to neurotoxicity. On the other hand, caffeine at low doses produces antioxidant effects (Abreu et al. 2011; Gołembiowska et al. 2008, 2013; Górska et al. 2014; RuizMedina et al. 2013; Sinchai et al. 2011) and reduces neurotoxic effect exerted by various toxins. Therefore, further studies especially after prolonged exposure to caffeine and MDMA in animal models are necessary to understand the mechanism of its neurotoxicity. 
In conclusion, the findings of our study demonstrate that caffeine exacerbates the MDMA effect on DA and 5-HT release in the mouse striatum. Its effect is mimicked by selective antagonists of adenosine $\mathrm{A} 1$ and $\mathrm{A} 2 \mathrm{~A}$ receptors corroborating the role of these receptors in the caffeine effect. The summary of our findings is presented in a diagram in Fig. 8. Our neurochemical data may help to understand the mechanism of MDMA neurotoxicity when it is used recreationally in combination with other concomitants, such as caffeine.

Acknowledgments This article was supported by statutory funds from the Institute of Pharmacology, Polish Academy of Sciences (Kraków, Poland). Thanks are due to MS Karolina NoworytaSokołowska for her kind technical assistance.

\section{Conflict of interest None}

Open Access This article is distributed under the terms of the Creative Commons Attribution License which permits any use, distribution, and reproduction in any medium, provided the original author(s) and the source are credited.

\section{References}

Abreu RV, Silva-Oliveira EM, Moraes MFD, Pereira GS, MoraesSantos T (2011) Chronic coffee and caffeine ingestion effects on the cognitive function and antioxidant system of rat brains. Pharmacol Biochem Behav 99:659-664

Alex KD, Pehek EA (2007) Pharmacologic mechanisms of serotonergic regulation of dopamine neurotransmission. Pharmacol Ther 113:296-320

Aoyama S, Kase H, Borrelli E (2000) Rescue of locomotor impairment in dopamine D2 receptor-deficient mice by an adenosine A2A receptor antagonist. J Neurosci 20:5848-5852

Baumann MH, Clark RD, Budzynski AG, Partilla JS, Blough BE, Rothman RB (2005) N-substituted piperazines abused by humans mimic the molecular mechanism of 3,4-methylenedioxymethamphetamine (MDMA, or "ecstasy"). Neuropsychopharmacology 30:550-560

Baumann MH, Wang X, Rothman RB (2007) 3,4-Methylenedioxymethamphetamine (MDMA) neurotoxicity in rats: a reappraisal of past and present findings. Psychopharmacology 189:407-424

Björklund O, Halldner-Henriksson L, Yang J, Eriksson TM, Jacobson MA, Daré E, Fredholm BB (2008) Decreased behavioral activation following caffeine, amphetamine and darkness in A3 adenosine receptor knock-out mice. Physiol Behav 95:668-676

Borycz J, Pereira MF, Melani A, Rodrigues RJ, Köfalvi A, Panlilio L et al (2007) Differential glutamate-dependent and glutamateindependent adenosine A1 receptor-mediated modulation of dopamine release in different striatal compartments. J Neurochem 101:355-363

Capela JP, Carmo H, Remião F, Bastos ML, Meisel A, Carvalho F (2009) Molecular and cellular mechanisms of ecstasy-induced neurotoxicity: an overview. Mol Neurobiol 39:210-271

Castagnoli N, Petzer JP, Steyn S, Castagnoli K, Chen J-F, Schwarzschild MA et al (2003) Monoamine oxidase B inhibition and neuroprotection. Studies on selective adenosine $\mathrm{A}_{2 \mathrm{~A}}$ receptor antagonists. Neurology 61(suppl 6):S62-S68
Chen GJ, Harvey BK, Shen H, Chou J, Victor A, Wang Y (2006) Activation of adenosine receptor reduces ischemic brain injury in rodents. J Neurosci Res 84:1848-1855

Chen J-F, Yu L, Shen H-Y, He J-C, Wang X, Zheng R (2010) What knock-out animals tell us about the effects of caffeine. J Alzheimer's Dis 20:S17-S24

Ciruela F, Casadó V, Rodrigues RJ, Luján R, Burgueño J, Canals M et al (2006) Presynaptic control of striatal glutamatergic neurotransmission by adenosine $\mathrm{A}_{1}-\mathrm{A}_{2 \mathrm{~A}}$ receptors heteromers. J Neurosci 26:2080-2087

Colado MI, Camarero J, Mechan AO, Sanchez V, Esteban B, Elliott JM et al (2001) A study of the mechanisms involved in the neurotoxic action of 3,4-methylenedioxymethamphetamine (MDMA, "ecstasy") on dopamine neurons in mouse brain. $\mathrm{Br}$ J Pharmacol 134:1711-1723

Costa G, Simola N, Morelli M (2014) MDMA administration during adolescence exacerbates MPTP-induced cognitive impairment and neuroinflammation in the hippocampus and prefrontal cortex. Psychopharmacology. doi:10.1007/s00213-014-3536-Z

Czuczwar SJ, Janusz W, Szczepanik B, Kleinrok Z (1991) Influence of CGS 15943 A (a nonxanthine adenosine antagonist) on the protection offered by a variety of antiepileptic drugs against maximal electroshock-induced seizures in mice. J Neural Transm 86:127-134

Davies S, Lee T, Ramsey J, Dargan PI, Wood DM (2012) Risk of caffeine toxicity associated with the use of 'legal highs' (novel psychoactive substances). Eur J Clin Pharmacol 68:435-439

Faure P, Tolu S, Valverde S, Naudé J (2014) Role of nicotinic acetylcholine receptors in regulating dopamine neuron activity. Neuroscience. doi:10.1016/j.neuroscience.2014.05.040

Fenu S, Pinna A, Ongini E, Morelli M (1997) Adenosine A2A receptor antagonism potentiates L-DOPA-induced turning behaviour and c-fos expression in 6-hydroxydopamine-lesioned rats. Eur J Pharmacol 321:143-147

Ferré S, Fredholm BB, Morelli M, Popoli P, Fuxe K (1997) Adenosine-dopamine receptor-receptor interactions as an integrative mechanism in the basal ganglia. Trends Neurosci 20:482-487

Fornai F, Lenzi P, Frenzilli G, Gesi M, Ferrucci M, Lazeri G et al (2004) DNA damage and ubiquitinated neuronal inclusions in the substantia nigra and striatum of mice following MDMA (ecstasy). Psychopharmacology 173:353-363

Francis JE, Cash WD, Psychoyos S, Ghai G, Wenk P, Friedmann RC et al (1988) Structure-activity profile of a series of novel triazoloquinazoline adenosine antagonists. J Med Chem 31:1014-1020

Fredholm BB, Abbracchio MP, Burnstock G, Daly JW, Harden TK, Jacobson KA et al (1994) Nomenclature and classification of purinoceptors. Pharmacol Rev 46:143-156

Fredholm BB, Bättig K, Holmén J, Nehlig A, Zvartau EE (1999) Actions of caffeine in the brain with special reference to factors that contribute to its widespread use. Pharmacol Rev 51:83-133

Fredholm BB, Irenius E, Kull B, Schulte G (2001) Comparison of the potency of adenosine as an agonist at human adenosine receptors expressed in Chinese hamster ovary cells. Biochem Pharmacol 61:443-448

Garret BE, Holtzman SG (1994) D1 and D2 dopamine receptor antagonists block caffeine-induced stimulation of locomotor activity in rats. Pharmacol Biochem Behav 47:89-94

Gołembiowska K, Dziubina A (2012) The effect of adenosine A2A receptor antagonists on hydroxyl radical, dopamine, and glutamate in striatum of rats with altered function of VMAT2. Neurotox Res 22:150-157

Gołembiowska K, Żylewska A (1997) Adenosine receptors: the role in modulation of dopamine and glutamate release in the rat striatum. Pol J Pharmacol 49:317-322 
Gołembiowska K, Żylewska A (1998) Agonists of $\mathrm{A}_{1}$ and $\mathrm{A}_{2 \mathrm{~A}}$ adenosine receptors attenuate methamphetamine-induced overflow of dopamine in rat striatum. Brain Res 806:202-209

Gołembiowska K, Dziubina A, Kowalska M, Kamińska K (2008) Paradoxical effects of adenosine receptor ligands on hydroxyl radical generation by L-DOPA in the rat striatum. Pharmacol Rep 60:319-330

Gołembiowska K, Dziubina A, Kowalska M, Kamińska K (2009) Effect of adenosine A2A receptor antagonists on L-DOPAinduced hydroxyl radical formation in rat striatum. Neurotox Res 15:155-166

Gołembiowska K, Wardas J, Noworyta-Sokołowska K, Kamińska K, Górska A (2013) Effects of adenosine receptor antagonists on the in vivo LPS-induced inflammation model of Parkinson's disease. Neurotox Res 24:29-40

Górska AM, Noworyta-Sokołowska K, Gołembiowska K (2014) The effect of caffeine on MDMA-induced hydroxyl radical production in the mouse striatum. Pharmacol Rep 66:718-721

Griebel G, Saffroy-Spittler M, Misslin R, Remmy D, Vogel E, Bourguignon J-J (1991) Comparison of the behavioural effects of an adenosine A1/A2-receptor antagonist, CGS 15943A, and an A1-selective antagonist, DPCPX. Psychopharmacology 103:541-544

Gudelsky GA, Nash JF (1996) Carrier-mediated release of serotonin by 3,4-methylenedioxymethamphetamine: implications for serotonin-dopamine interactions. J Neurochem 66:243-249

Gudelsky GA, Yamamoto BK (2008) Actions of 3,4-methylenedioxymethamphetamine (MDMA) on cerebral dopaminergic, serotonergic and cholinergic neurons. Pharmacol Bioch Behav 90:198-207

Hadfield MG, Milio C (1989) Caffeine and regional brain monoamine utilization in mice. Life Sci 45:2637-2644

Han DD, Gu HH (2006) Comparison of the monoamine transporters from human and mouse in their sensitivities to psychostimulant drugs. BMC Pharmacol 6:1-7

Ikeda R, Igari Y, Fuchigami Y, Wada M, Kuroda N, Nakashima K (2011) Pharmacodynamic interactions between MDMA and concomitants in MDMA tablets on extracellular dopamine and serotonin in the rat brain. Eur J Pharmacol 660:318-325

Jacobson KA, Van Rhee AM (1997) Development of selective purinoceptor agonists and antagonists. In: Jacobson KA, Jarvis MF (eds) Purinergic approaches in experimental therapeutics. Wiley, New York, pp 101-128

Kermanian F, Mehdizadeh M, Soleimani M, Bideskan ARE, AsadiShekaari M, Kheradmand H, Haghir H (2012) The role of adenosine receptor agonist and antagonist on hippocampal MDMA detrimental effects; a structural and behavioral study. Matab Brain Dis 27:459-469

Khairnar A, Plumitallo A, Frau L, Schintu N, Morelli M (2010) Caffeine enhances astroglia and microglia reactivity induced by 3,4-methylenedioxymethamphetamine ('Ecstasy') in mouse brain. Neurotox Res 17:435-439

Kuzmin A, Johansson B, Gimenez L, Ögren SO, Fredholm BB (2006) Combination of adenosine $A_{1}$ and $A_{2 A}$ receptor blocking agents induces caffeine-like locomotor stimulation in mice. Eur Neuropsychopharmacol 16:129-136

Lazarus M, Shen H-Y, Cherasse Y, Qu W-M, Huang Z-L, Bass CE et al (2011) Arousal effect of caffeine depends on adenosine $A_{2 A}$ receptors in the shell of the nucleus accumbens. J Neurosci 31:10067-10075

Linden J (1994) Cloned adenosine A3 receptors: pharmacological properties, species differences and receptors function. Trends Pharmacol Sci 15:298-306

McNamara R, Kerans A, O’Neill B, Harkin A (2006) Caffeine promotes hyperthermia and serotonergic loss following co- administration of the substituted amphetamines, MDMA ("Ecstasy") and MDA ("Love"). Neuropharmacology 50:69-80

Morgan ME, Vestal RE (1989) Methylxanthine effects on caudate dopamine release as measured by in vivo electrochemistry. Life Sci 45:2025-2039

Nikodijeviç O, Jacobson KA, Daly JW (1993) Locomotor activity in mice during chronic treatment with caffeine and withdrawal. Phamacol Biochem Behav 44:199-216

Okada M, Mizuno K, Kaneko S (1996) Adenosine A1 and A2 receptors modulate extracellular dopamine levels in rat striatum. Neurosci Lett 212:53-56

Okada M, Kawata Y, Murakami T, Wada K, Misuno K, Kondo T et al (1999) Differential effects of adenosine receptor subtypes on release and reuptake of hippocampal serotonin. Eur J Neurosci 11:1-9

Paxinos G, Franklin KBJ (2001) The mouse brain. In: Stereotaxic coordinates, 2nd edn. Academic Press, San Diego

Petzer JP, Steyn S, Castagnoli KP, Chen J-F, Schwarzschild MA, Van der Schyf CJ, Castagnoli N (2003) Inhibition of monoamine oxidase $\mathrm{B}$ by selective adenosine $\mathrm{A}_{2 \mathrm{~A}}$ receptor antagonists. Bioorg Med Chem 11:1299-1310

Petzer A, Pienaar A, Petzer JP (2013) The interactions of caffeine with monoamine oxidase. Life Sci 93:283-287

Popoli P, Gimenez-Llort L, Pezzola A, Reggio R, Martinez E, Fuxe K et al (1996) Adenosine A1 receptor blockade selectively potentiates the motor effects induced by dopamine D1 receptor stimulation in rodents. Neurosci Lett 218:209-213

Ruiz-Medina J, Pinto-Xavier A, Rodríguez-Arias M, Miñarro J, Valverde O (2013) Influence of chronic caffeine on MDMAinduced behavioral and neuroinflammatory response in mice. Psychopharmacology 226:433-444

Saki M, Yamada K, Koshimura E, Sasaki K, Kanda T (2013) In vitro pharmacological profile of the $\mathrm{A}_{2 \mathrm{~A}}$ receptor antagonist istradefylline. Naunyn-Schmiedeberg's Arch Pharmacol 386:963-972

Schmitt KC, Reith MEA (2010) Regulation of dopamine transporter. Aspects relevant to psychostimulant drugs of abuse. Ann NY Acad Sci 1187:316-340

Sinchai T, Plasen S, Sanvarinda Y, Jaisin Y, Govitrapong P, Motrales NP et al (2011) Caffeine potentiates methamphetamine-induced toxicity both in vitro and in vivo. Neurosci Lett 502:65-69

Singh S, Singh K, Gupta SP, Patel DK, Singh RK, Singh P (2009) Effect of caffeine on the expression of cytochrome P450 1A2, adenosine $\mathrm{A} 2 \mathrm{~A}$ receptor and dopamine transporter in control and 1-methyl-4-phenyl-1,2,3,6-tetrahydropyridine treated mouse striatum. Brain Res 1283:115-126

Sprague JE, Everman SL, Nichols DE (1998) An integrated hypothesis for serotonergic axonal loss induced by 3,4-methylenedioxymethamphetamine. Neurotoxicology 19:427-441

Sulzer D, Sonders MS, Poulsen NW, Galli A (2005) Mechanisms of neurotransmitter release by amphetamines: a review. Prog Neurobiol 75:406-433

Svenningsson P, Nergårdh R, Fredholm BB (1998) Regional differences in the ability of caffeine to affect haloperidol-induced striatal $c$-fos mRNA expression in the rat. Neuropharmacology 37:331-337

Vanattou-Saïfoudine N, McNamara R, Harkin A (2010) Mechanisms mediating the ability of caffeine to influence MDMA ('Ecstasy')induced hyperthermia in rats. Br J Pharmacol 160:860-877

Vanattou-Saïfoudine N, Gossen A, Harkin A (2011) A role for adenosine A1 receptor blockade in the ability of caffeine to promote MDMA "Ecstasy"-induced striatal dopamine release. Eur J Pharmacol 650:220-228

Xie T, Tong L, McLane MW, Hatzidimitriou G, Yuan J, McCann U, Ricaurte GA (2006) Loss of serotonin transporter protein after MDMA and other ring-substituted amphetamines. Neuropsychopharmacology 31:2639-2651 
Yacoubi ME, Ledent C, Parmentier M, Ongini E, Costentin J, Vaugeois J-M (2001) In vivo labelling of the adenosine $A_{2 A}$ receptor in mouse brain using the selective antagonist $\left[{ }^{3} \mathrm{H}\right] \mathrm{SCH}$ 58261. Eur J Neurosci 14:1567-1570

Yamamoto BK, Spanos LJ (1988) The acute effects of methylenedioxymethamphetamine on dopamine release in the awakebehaving rat. Eur J Pharmacol 148:195-203
Youdim MB, Edmondson D, Tipton KF (2006) The therapeutic potential of monoamine oxidase inhibitors. Nat Rev Neurosci 7:295-309

Yu L, Shen HY, Coelho JE, Araúlo IM, Huang QY, Day YJ, Rebola $\mathrm{N}$ et al (2008) Adenosine $\mathrm{A}_{2 \mathrm{~A}}$ receptor antagonists exert motor and neuroprotective effects by distinct cellular mechanisms. Ann Neurol 63:338-346 